\title{
An acid-stable laccase from Sclerotium rolfsii with potential for wool dye decolourization
}

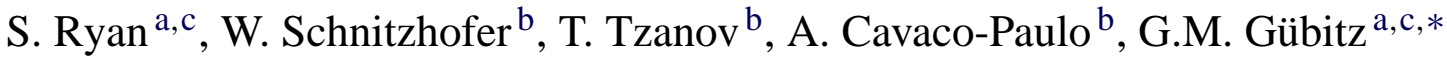 \\ a Sucher\&Holzer GmbH, Alberstrasse 4, A-8010 Graz, Austria \\ ${ }^{\mathrm{b}}$ Department of Textile Engineering, University of Minho, 4800 Guimaraes, Portugal \\ ${ }^{c}$ Department of Environmental Biotechnology, Graz University of Technology, Petersgasse 12, A-8010 Graz, Austria
}

Received 17 July 2002; received in revised form 30 April 2003; accepted 3 May 2003

\begin{abstract}
The plant pathogen basidiomycete $S$. rolfsii secretes two laccases (SRL1 and SRL2) with molecular weights of 55 and $86 \mathrm{kDa}$, respectively. Laccase production was shown to be inducible by the addition of 2,5-xylidine to the cultural media. After treatment with a combination of chitinase and $\beta$-1,3-glucanase, two different laccases were isolated from the sclerotia depending on the stage of sclerotia development. The more prominent laccase, SRL1, was purified and found to decolourize the industrially important wool azo dye Diamond Black PV 200 without the addition of redox mediators. The enzyme (pI 5.2) was active in the acidic pH range, showing an optimal activity at $\mathrm{pH}$ 2.4, with ABTS as substrate. The optimum temperature for activity was determined to be $62{ }^{\circ} \mathrm{C}$. Enzyme stability studies revealed that SRL1 was notably stable at $18^{\circ} \mathrm{C}$ and $\mathrm{pH} 4.5$, retaining almost full activity after a week. Oxidation of tyrosine was not detectable under the reaction conditions but the enzyme did oxidize a variety of the usual laccase substrates. SRL1 was strongly inhibited by sodium azide and fluoride. Dye solutions decolourized with the immobilized laccase were successfully used for redyeing.
\end{abstract}

(C) 2003 Elsevier Inc. All rights reserved.

Keywords: Laccase; Sclerotium rolfsii; Purification; Characterization

\section{Introduction}

Laccases (benezenediol:oxygen oxidoreductase, EC 1.10.3.2) are multinuclear copper-containing enzymes that catalyse the oxidation of a variety of phenolic and inorganic compounds, with the concomitant reduction of oxygen to water [1]. Although primarily originating from fungi [2,3], laccases are widely distributed in nature and have also been detected in plants [4], insects [5] and bacteria [6]. These oxidative enzymes are particularly abundant in white-rot basidiomycete fungi, which are capable of degrading lignin in vivo. Accordingly, this class of fungi has been extensively researched as potential producers of laccase activity. To date, extracellular laccases have been purified from numerous fungal sources such as Pleurotus eryngii [7], Coriolus hirsutus [8] and Pycnoporus cinnabarinus [9].

Due to their wide substrate specificity laccases have gained much attention over the last number of years in many industrial and environment fields. Of particular com-

\footnotetext{
* Corresponding author. Tel.: +43-316-873-8312; fax: +43-316-873-8815.

E-mail address: guebitz@ima.tu-graz.ac.at (G.M. Gübitz).
}

mercial interest is the potential use of these enzymes to decolourize dyes. By means of enzymatic catalyzed oxidative reactions, laccase can detoxify phenolic contaminants, such as aromatic amines, to harmless/less harmful products [10]. The suitability of laccases for such processes has been known for some time [11] and successful results achieved have been well documented by our group [12] and others $[13,14]$. These being of primary importance to the textile industry, dyes and dyestuffs are commonly used in the pharmaceutical, food, cosmetic and leather industries. Stringent environmental legislation imposed to control the release of dyestuffs in wastewater poses particular problems for the textile industry. Up to $20 \%$ of dye is lost into the wastewater during the dyeing process although this figure depends on the class of dye application. It is known that $90 \%$ of reactive textile dyes entering activated sludge sewage treatment plants will pass through unchanged and be discharged to rivers [15]. Laccases, especially when used immobilized on carrier materials, are seen as attractive options in the development of an effective strategy for the biological treatment of wastewater. In particular, the reuse of enzymatically treated dyeing effluents could help to reduce water consumption [16]. 
The process of wool dying, carried out in the acidic $\mathrm{pH}$ range from $\mathrm{pH} 3.8$ to 4.4 uses primarily acid dyes which promote the adhesion of the dye through ionic interactions between the dye and the wool. Acid dyes have hydroxyl, carboxyl or sulphonic groups with an overall negative charge. The enzymatic elimination of these dyes from the dyeing effluent requires an acid-stable laccase. The phytopathogenic fungus, Sclerotium rolfsii, which secretes an acid-stable laccase has been investigated in this study in terms of purification, biochemical characterization and for the ability of its laccase to decolourize acidic dyes. Although $S$. rolfsii has been extensively studied as a producer of cellulolytic and hemicelluloytic enzymes $[17,18]$, its capacity to produce oxidative enzymes has been explored to a lesser extent [19]. Furthermore, until now there is no information available on whether the laccases produced during the formation of sclerotia are different to those secreted by the mycelium of $S$. rolfsii [20].

Sclerotia are small, compact, usually spherical reproductive bodies, comprising of a cell wall containing three layers; and ranging in size from $100 \mathrm{~mm}$ (plant pathogens) to $1 \mathrm{~cm}$ in omnivorous types. Sclerotia have a high resistance to chemical and biological degradation and play a vital role in the survival of the organism for extended periods of time [21]. Two types of germinating patterns exist: Carpogenic sclerotia, which produces a sexual fruiting body, as seen in the species Claviceps and the second form of sclerotia production, called Myceliogenic sclerotia, characteristic of S. rolfsii, develop from repeated localized hyphal branching followed by adhesion of the branches. Outer hyphae are crushed to form the rind of thick-walled melanized cells while the inner tissue stores nutrient reserves and become swollen, with extended vacuoles [21]. Laccases can be involved in pigment synthesis (polymerization of melanin) in differentiated fungal structures as shown for Aspergillus nidulans [22]. Laccases produced by $S$. rolfsii during formation of sclerotia and secreted by the mycelium could have different specificities and stabilities and thus, show a different behavior in dye degradation.

\section{Materials and methods}

\subsection{Organism and culture conditions}

S. rolfsii (CBS 350.80) was obtained from the University of Agriculture Science, Vienna, Austria. The culture was maintained on PDA-agar plates grown at $30^{\circ} \mathrm{C}$, stored at $4{ }^{\circ} \mathrm{C}$ and subcultured monthly. For laccase production S. rolfsii was grown in $1000 \mathrm{ml}$ Erlenmeyer flasks at $30 \pm 1{ }^{\circ} \mathrm{C}$ on an orbital shaker at $150 \mathrm{rpm}$ using $300 \mathrm{ml}$ culture medium containing the following ingredients: $42.6 \mathrm{~g}$ cellulose, $40 \mathrm{~g}$ meat peptone, $2.5 \mathrm{~g} \mathrm{NH}_{4} \mathrm{NO}_{3}, 1.5 \mathrm{~g} \mathrm{MgSO}_{4}, 1.0 \mathrm{~g} \mathrm{KH}_{2} \mathrm{PO}_{4}$, $0.5 \mathrm{~g} \mathrm{KCl}$, and $300 \mu \mathrm{l}$ trace element solution [23] in 11 distilled water. The initial $\mathrm{pH}$ was adjusted to 5.5 and the growth medium was sterilized at $121^{\circ} \mathrm{C}$ for $15 \mathrm{~min}$ prior to inoculation with $1 \mathrm{~cm}^{2}$ discs of fungus growing on agar plates.
In order to induce laccase activity various phenolic agents $\left(1 \mathrm{~g}^{-1}\right)$ were added through sterile filters to the fermentation broth at the point of inoculation. These included caffeic acid, ferulic acid, gallic acid and pectin. 2,5-Xylidine in concentrations ranging from 10 to $100 \mu \mathrm{M}$ was added to the culture medium after three days of cultivation. For the purpose of enzyme purification $10 \mu \mathrm{M}$ of 2,5 -xylidine plus $1 \%$ pectin was used to stimulate laccase activity. The fermentation continued for a total of 9 days after which the culture supernatant was harvested by centrifugation at $10,000 \times g$ for $10 \mathrm{~min}$.

\subsection{Production of sclerotia}

On agar plates, sclerotia development was visible after 9 days of growth. These structures were white (W) in appearance and matured to a light brown (LB) colour within another 6 days. The final stage of maturity was attained on approximately day 20 of growth when the sclerotia developed into a dark brown (DB) colour, characteristic of the mature sclerotia of the species. This process of sclerotia formation was continuous and at various stages of growth all forms were simultaneous present on the plate.

Sclerotia were harvested at the white (W), light (LB) and dark brown (DB) stages of development. To achieve this they were gently picked from their stems to detach them from the mycelial bed. Sclerotia were subsequently placed in a sieve and washed repeatedly with distilled water to remove any mycelia that remained attached. The wet weight $(\mathrm{g})$ of the sclerotia was determined. Samples were ground using a mortar and pestle after which they were transferred to centrifuge tubes. Centrifugation at $8000 \mathrm{rpm}$ and for $10 \mathrm{~min}$ was used to separate the insoluble material. The supernatant containing the enzyme of interest was decanted. The pellet was subsequently washed with $50 \mathrm{mM}$ sodium-acetate buffer $(\mathrm{pH} 4.0)$ and re-centrifuged. The supernatant was added to that collected after the first centrifugation step. This sample was kept at $4{ }^{\circ} \mathrm{C}$ for future analysis and the pellet discarded. After some weeks of growing on agar plates a brown/yellow liquid was secreted onto the surface. This liquid $(\mathrm{L})$ was also harvested, assayed for laccase activity and developed on SDS non-denaturing gels.

Trichoderma harzianum was cultivated and the major chitinase and $\beta$-1,3-glucanase purified as previously described [24]. Mature sclerotia were harvested and incubated overnight with chitinase and/or endoglucanase enzymes at $30^{\circ} \mathrm{C}$. After $24 \mathrm{~h}$ the samples were centrifuged and the pellet removed while the supernatant was assayed to determine if the added hydrolase activities successfully degraded the sclerotia cell wall and released the laccase activity. Control samples were run in parallel with buffer instead of enzyme.

\subsection{Enzyme and protein assay}

Laccase activity was measured at $25^{\circ} \mathrm{C}$ by following the change in optical density at $436 \mathrm{~nm}$ using ABTS as substrate 
$\left(\varepsilon=29.2 \mathrm{mM}^{-1} \mathrm{~cm}^{-1}\right)$. The reaction mixture contained $1.15 \mathrm{ml}$ of suitably diluted enzyme using $25 \mathrm{mM}$ succinate buffer $\mathrm{pH} 4.5$ and $0.35 \mathrm{ml}$ ABTS according to published methods [25]. Activity on other substrates was measured similarly at their wavelength maxima. Protein concentration was routinely determined using the Bradford Reagent (Sigma) according to the manufacturer's instructions with bovine serum albumin as standard. All chromatographic runs were monitored for protein by absorbance at $280 \mathrm{~nm}$. The inhibitory effects of a number of reagents as indicated below were studied at various concentrations using the standard ABTS assay to monitor the effects on laccase activity. The inhibitor was added 10 min prior to substrate addition.

\subsection{Enzyme purification}

Proteins were precipitated from the culture supernatent by the gradual addition of ammonium sulphate up to $85 \%$ saturation. The resultant pellet was resuspended in $10 \mathrm{mM}$ sodium acetate buffer, $\mathrm{pH} 4.75$ and $\left(\mathrm{NH}_{4}\right)_{2} \mathrm{SO}_{4}$ was added to a final concentration of $1.1 \mathrm{M}$. It was then loaded onto a Phenyl Sepharose CL-4B (Pharmacia) column $(70 \mathrm{ml}$, pre-equilibrated with $1.1 \mathrm{M}\left(\mathrm{NH}_{4}\right)_{2} \mathrm{SO}_{4}$. Elution of proteins was achieved using an isocratic gradient of $1.1-0.0 \mathrm{mM}$ $\left(\mathrm{NH}_{4}\right)_{2} \mathrm{SO}_{4}$. Laccase active fractions were pooled, concentrated and dialysed against $10 \mathrm{mM}$ sodium acetate buffer, pH 4.75 and applied to a Q-Sepharose FF (Pharmacia) column $(10 \mathrm{ml})$ pre-equilibrated with $10 \mathrm{mM}$ sodium acetate, $\mathrm{pH}$ 4.75. The active fractions that remained bound to the column after the wash were eluted by a linear gradient of $0-0.5 \mathrm{M} \mathrm{NaCl}$. The fractions were subsequently pooled, concentrated and dialysed against $1.0 \mathrm{mM}$ sodium phosphate buffer $\mathrm{pH}$ 6.8. The sample was loaded onto a hydroxyapatite column $(5 \mathrm{ml})$ pre-equilibrated with the same buffer. The active laccase fractions were eluted using a linear gradient of $1-25 \mathrm{mM}$ sodium phosphate buffer ( $\mathrm{pH}$ 6.8). Concentration steps were performed throughout the purification using an ultrafiltration stirred cell apparatus (Amicon Corp., Lexington, MA), using a 10-kDa PS membrane.

\subsection{Electrophoresis and staining}

SDS gel electrophoresis was performed according to the method of Laemmli (1970) using 10\% gels and Coomassie Blue for protein staining. To detect laccase activity after SDS-PAGE, prior to gel application samples were incubated at $50^{\circ} \mathrm{C}$ for $20 \mathrm{~min}$. Following Coomassie Blue staining the gels were destained, rinsed with water and subsequently submerged in $3 \mathrm{mM}$ ABTS where the laccase active band was highlighted in green. Isoelectric focusing (IEF) was carried out with the Mini-PROTEAN 3 cell from Bio-Rad using IEF Ready Gels (pH 3-10, Bio-Rad). Protein was visualized using Coomassie Blue.

\subsection{Determination of temperature and $\mathrm{pH}$ optima and stabilities}

Optimum temperature for the activity of the laccase was determined by carrying out the standard laccase assay at selected constant temperatures ranging from 25 to $65^{\circ} \mathrm{C}$. In each case the substrate was preincubated at the required temperature. The $\mathrm{pH}$ optimum was determined at a fixed assay temperature of $30^{\circ} \mathrm{C}$ at various $\mathrm{pH}$ values between pH 2.2 and 7.0 using Mcllvaine-type constant ionic strength citrate-phosphate buffer. In order to study the thermal stability, diluted enzyme samples $(100 \mathrm{mM}$ succinate buffer, $\mathrm{pH}$ 4.5) were incubated for fixed time periods at $30,60,80^{\circ} \mathrm{C}$. At time intervals, the $\mathrm{pH}$ of the incubation mixture was measured and aliquots were withdrawn and were cooled on ice before assaying to determine the residual enzyme activity, using the normal assay procedure. The stability of the enzyme at various $\mathrm{pH}$ values was determined by preincubating the enzyme at the desired $\mathrm{pH}$ for a fixed period at $30^{\circ} \mathrm{C}$. Residual enzyme activity was determined using the standard assay procedure.

\section{7. $K_{m}$ and $V_{\max }$ determination}

$K_{\mathrm{m}}$ and $V_{\max }$ constants were determined using various concentrations of ABTS $(0.05-20 \mathrm{mM})$ and syringaldazine (4-hydroxy-3,5-dimethoxybenzaldehyde azine; $2-85 \mu \mathrm{M}$ ) as substrate using the normal assay procedures. The experimental data were analyzed according to the Michaelis-Menten model by Lineweaver-Burk plots and by non-linear regression analysis using the program Origin 5.0.

\subsubsection{Enzyme immobilization}

Alumina pellets were silanized at $45^{\circ} \mathrm{C}$ for $24 \mathrm{~h}$ in a $2.5 \%$ $(\mathrm{v} / \mathrm{v})$ solution of $\gamma$-aminopropyltriethoxy silane in acetone. The silanized pellets were washed with distilled water and immersed in $2 \%(\mathrm{v} / \mathrm{v})$ aqueous glutaraldehyde for $2 \mathrm{~h}$ at $20^{\circ} \mathrm{C}$. Thereafter, the pellets were incubated with $60 \mathrm{mg} \mathrm{l}^{-1}$ of the crude enzyme preparation (obtained after ammonium sulphate precipitation of the culture filtrate) for $5 \mathrm{~h}$ at $20^{\circ} \mathrm{C}$. The immobilized enzyme pellets were washed with potassium phosphate buffer (100 mM, pH 7.0) and kept refrigerated until further use.

\subsection{Decolourization experiments}

The reaction mixture consisted of a final volume of $1 \mathrm{ml}$ and contained $50 \mu \mathrm{l}$ enzyme ( $3.3 \mathrm{nkat} \mathrm{ml}^{-1}$ final activity), buffer (50 mM sodium acetate, $\mathrm{pH} 4.5$ ) and Diamond Black (DB) (Dye Star, maximum absorption $536 \mathrm{~nm}$ ) dye solution at a specified concentration. The reaction was carried out at $40^{\circ} \mathrm{C}$ and the colour change monitored spectrophotometrically from 700 to $400 \mathrm{~nm}$. Control samples, containing denatured enzyme, were run in parallel under identical conditions. Alternatively, the dye solution was continuously pumped $\left(0.1 \mathrm{ml}^{-1} \mathrm{~min}\right.$, dual-piston-pump) through a column 
$(15 \mathrm{~mm} \times 300 \mathrm{~mm})$ filled with immobilized laccase corresponding to about 30 nkat total laccase activity. Both column reactors and the flow cell were kept at $30^{\circ} \mathrm{C}$. Decolourization was monitored on a spectrophotometer equipped with a flow cell.

\subsection{Dyeing in enzymatically decolourised textile effluents}

$100 \%$ wool fabrics (samples of $0.5 \mathrm{~g}$ ) were dyed with C.I. Acid Blue 113 and C.I. Acid Yellow 49 (0.5, 1 and 1.5\% o.w.f. depth of shade) using an Ahiba Spectradye dyeing apparatus (Datacolor International, Luzern, Switzerland). The dyebaths were prepared with enzymatically decolourized liquors. Since starting concentrations of dyes in decolourization experiments were higher than in industrial effluents (to facilitate spectrophotometric monitoring) the decolourized solutions were diluted appropriately (1:3) with $0.1 \mathrm{M}$ sodium acetate buffer, $\mathrm{pH} 5$. The dye was added at $50^{\circ} \mathrm{C}$, and the temperature was raised to $100^{\circ} \mathrm{C}$ with $1^{\circ} \mathrm{C} \mathrm{min}-1$; at $100^{\circ} \mathrm{C}$ the dyeing continued for $1 \mathrm{~h}$. Colour differences of the dyed fabrics were determined using a reflectance measuring apparatus (Spectraflash 600 from Datacolor, Luzern, Switzerland) according to the CIELAB colour difference concept at standard illuminant $\mathrm{D}_{65}$ (LAV/Spec. Excl., d/8, $\mathrm{D}_{65} / 10^{\circ}$ ) with a colour tolerance interval of one CIELAB unit.

\section{Results and discussion}

\subsection{Induction of laccase in liquid culture}

Although laccase activity is apparently constitutive in most basidiomycetes, inducers such as aromatic substances have been reported to enhance activity [9,26-28]. To investigate the effect of some known laccase inducers, the growth medium of $S$. rolfsii was supplemented with different phenolic compounds. Growth was monitored using caffeic acid, ferulic acid, gallic acid, pectin, 2,5-xylidine and 2,5-xylidine plus pectin as inducers. The time course of laccase production revealed a steady increase in activity detectable in the extracellular fluid. A selection of the data is presented in Fig. 1. A moderate increase in specific activity was detected after the addition of xylidine alone. However, a combination of both xylidine and pectin (day 3) resulted in a dramatic increase in activity on day 9 and then decreased sharply towards the end of the experiment.

Interestingly, polygalacturonase (PG) activity was also increased by the inclusion of xylidine in the culture media (data not shown). It has been previously reported that pectin acts as a second inducer of extracellular laccase formation by Botrytis cinerea, in the presence of a phenolic substance as a first inducer, but pectin alone failed to induce enzyme formation [29]. Similar findings were noted when S. rolfsii was cultivated on a pectin induced medium without the phenolic inducer, xylidine. Experiments to determine if xylidine was toxic to the fungi at higher concentrations revealed that

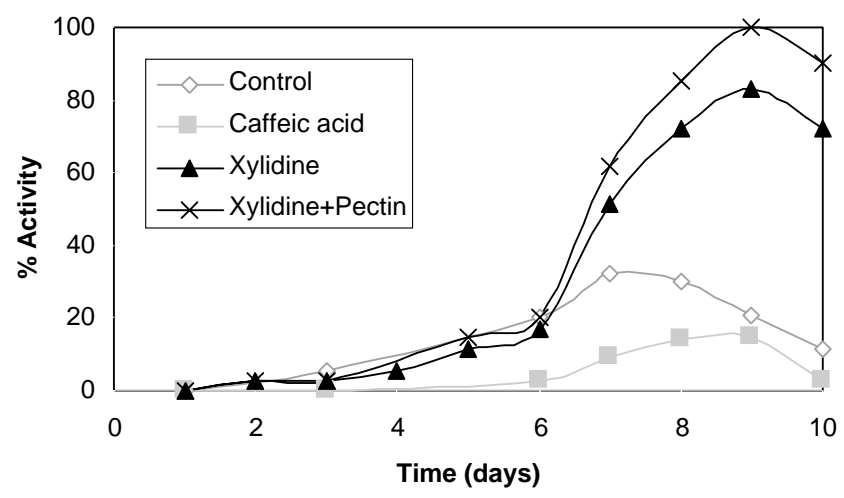

Fig. 1. Time course of laccase production by $S$. rolfsii in response to inducers added on day 3 .

similar levels of activity were reached regardless of the concentration over a test range of $1.0-0.1 \mathrm{mM}$. The other inducers assessed resulted in a significant decrease in the level of laccase activity.

As previously noted with other fungal species which included P. cinnabarinus [30], Rigidoporus lignosus [31], Trametes pubescens [32] and Phanerochaete chrysosporium [33] more than one extracellular laccase isoform is often produced during cultivation. S. rolfsii secreted two electrophoretically distinct proteins displaying laccase activity. Their molecular masses were 55 and $86 \mathrm{kDa}$, respectively, as determined by SDS-PAGE with activity staining (Fig. 2). In general, after Coomassie Blue staining the same pattern of bands on SDS-PAGE gels was obtained regardless the temperature used for sample pretreatment (boiling or $50^{\circ} \mathrm{C}$ for activity staining).

\subsection{Laccases from sclerotia}

Sclerotia grew increasingly dense as they reached maturity and a liquid, yellow in colour was secreted from the sclerotia,

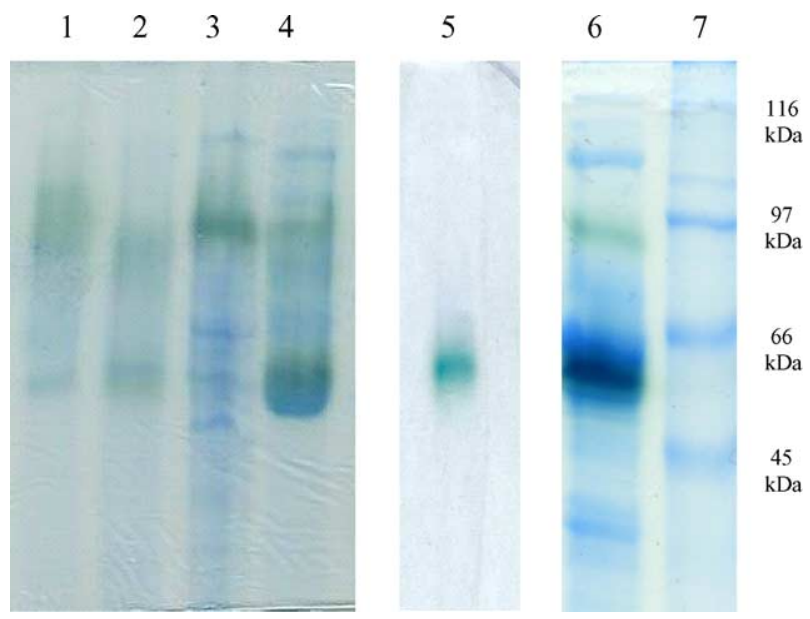

Fig. 2. Coomassie Blue and ABTS stained SDS-PAGE gel. Lane 1-LB (light brown), lane 2-DB (dark brown), lane 3-W (white), lane 4-L (liquid), lane 5-purified laccase, lane 6-crude extracellular laccases and lane 7-molecular weight standards $(\mathrm{kDa})$. 
Table 1

Laccase activity present at various stages of sclerotia growth

\begin{tabular}{lccc}
\hline Stage of development & $\begin{array}{c}\text { Weight of sclerotia } \\
\text { harvested }(\mathrm{mg})\end{array}$ & $\begin{array}{l}\text { Total laccase } \\
\text { activity (nkat) }\end{array}$ & $\begin{array}{c}\text { Paccase activity per } \\
\text { wet weight }(\mathrm{nkat} / \mathrm{g})\end{array}$ \\
\hline White (W) & 50 & 0.156 & 3.1 \\
Light brown (LB) & 110 & 0.378 & 3.5 \\
Dark brown (DB) & 50 & 0.346 & 17 \\
Liquid & n.a. & 0.384 & 12 \\
n.a & & 17
\end{tabular}

n.a.: not applicable.

apparently at the DB stage of development. This was assayed for laccase activity which was detected. Laccase activity, although present in all stages of sclerotia development, was slightly more predominant in the DB sclerotia (Table 1).

In order to determine if the mycelial and sclerotial laccases had different molecular masses samples harvested from the various stages of growth were separated on SDS-gels. From the activity stain (ABTS) it was clear that the sclerotial laccases had identical $M_{\mathrm{r}}$ to those of the extracellular laccases secreted by the fungi when grown on liquid media, i.e. 55 and $86 \mathrm{kDa}$, respectively (Fig. 2). It appears that the higher molecular weight laccase is present in the white sclerotia, as the development continues the second laccase appears. It is thought that the laccases are involved in the pigmentation of the sclerotia.

Since only low amounts of laccase could be isolated from sclerotia, an enzymatic method for the hydrolysis of sclerotia was developed. The fungal wall usually consists of layers of chitin, a linear polysaccharide polymer of $\mathrm{N}$-acetylglucosamine, embedded in and often covered by glucans, branched polymers of glucose and other sugars. It was supposed that the action of chitinase together with $\beta$-1,3-glucanase could act to hydrolyse the chitin and $\beta-1,3$-glucan from the cell walls of the sclerotia structure and release the laccase activity. The $43 \mathrm{kDa}$ chitinase and $74 \mathrm{kDa} \beta$-1,3-glucanase were purified from the Trichoderma harzianum T24 culture filtrate as described previously [24]. When the harvested sclerotia were incubated separately with either of the two purified hydrolases, the laccase activity detectable in the supernatant was higher than that of the control (Table 2). When $\beta$-1,3-glucanase was applied directly to the sclerotia, an increase of $36 \%$ in laccase activity was observed compared to the buffer alone. The combined treatment of chitinase and $\beta-1,3$-glucanase resulted in a substantial increase in the laccase activity detectable, 4.5 times greater than the control sample. This result suggests that when loaded together the enzymes acted in a synergistic manner leading to an increase in the laccase levels present in the supernatant. Synergistic interactions between chitinase and $\beta$-1,3-glucanase during biocontrol of $S$. rolfsii have previously been described [24].

\subsection{Purification and molecular properties}

The lower molecular weight laccase SRL1, which was secreted in much higher amounts than the higher molecular weight laccase SRL2, was purified to homogeneity using four chromatographic steps according to the procedure summarized in Table 3 . The molecular mass of this polypeptide of $55 \mathrm{kDa}$ falls within the $M_{\mathrm{r}}$ range reported for many fungal laccases, which can range from 50 to $90 \mathrm{kDa}[2,3]$. An approximate purification of 183 fold was achieved with a final yield of $12 \%$. The isoelectric point of the pure enzyme was determined by IEF to be at $\mathrm{pH}$ 5.2.

Some properties of SRL1 are shown in Table 4. The $55 \mathrm{kDa}$ enzyme was very active in the acidic $\mathrm{pH}$ range, showing a peak at $\mathrm{pH} 2.4$ and a rapid decline in activity above $\mathrm{pH}$ 6.0, with ABTS as substrate. This property of SRL1 could potentially be exploited in the textile industry where acidic conditions predominate in wool dyeing. It should be noted however that the optimal $\mathrm{pH}$ for laccase activity is substrate dependent [34]. The optimum temperature for activity was determined to be $62{ }^{\circ} \mathrm{C}$. Enzyme stability studies revealed that SRL1 was highly stable at $18^{\circ} \mathrm{C}$ and $\mathrm{pH} 4.5$, retaining almost full activity after a week.

\subsection{Kinetic properties and substrate specificity}

The apparent $K_{\mathrm{m}}$ and $V_{\max }$ values of SRL1 were determined to be $0.22 \pm 0.03 \mathrm{mM}$ and $1.70 \pm 0.04$ nkat $\mathrm{ml}^{-1}$, respectively, with ABTS as substrate. When using

Table 2

Enzymatic treatment of sclerotia from S. rolfsii

\begin{tabular}{llllc}
\hline Sample & Sclerotia weight $(\mathrm{g})$ & $\begin{array}{l}\text { Laccase activity } \\
\text { (nkatal ml }{ }^{-1} \text { ) }\end{array}$ & \multicolumn{2}{c}{$\begin{array}{c}\text { Volume of sample (ml) } \\
\text { (nkatal) }\end{array}$} \\
\hline Chitinase $+\beta$-1,3-glucanase & 0.76 & 0.56 & 1.20 & 0.67 \\
s-1,3-Glucanase & 0.72 & 0.31 & 0.60 & 0.19 \\
Chitinase & 0.68 & 0.26 & 0.60 & 0.16 \\
Buffer & 0.71 & 0.23 & 0.60 & 0.26 \\
\hline
\end{tabular}


Table 3

Purification of the extracellular laccase SRL1 from Sclerotium rolfsii

\begin{tabular}{lccccc}
\hline Purification step & Total protein $(\mathrm{mg})$ & Total activity (nkatal) & Specific activity $\left(\mathrm{nkat} \mathrm{mg}^{-1}\right)$ & Yield $(\%)$ & Purification factor \\
\hline Culture extract & 362 & 720 & 1.9 & 100 & 85 \\
$75 \%\left(\mathrm{NH}_{4}\right)_{2} \mathrm{SO}_{4}$ & 308 & 616 & 2.0 & 60 & 1.02 \\
Phenyl-Sepharose & 33.8 & 431 & 68.8 & 29 & 7.9 \\
QFF & 3.04 & 209 & 245 & 12 & 183 \\
Hydroxapatite & 0.35 & 86 & & 12 & \\
\hline
\end{tabular}

syringaldazine as substrate, the apparent $K_{\mathrm{m}}$ and $V_{\max }$ values were estimated to be $0.087 \pm 0.005 \mathrm{mM}$ and

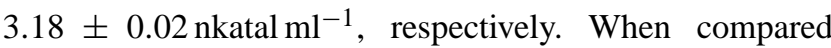
with other fungal laccases, SRL1 has high $K_{\mathrm{m}}$ values with 2,2'-azino-bis(3-ethylbenzothiazoline-6-sulfonic acid) and syringaldazine as substrates. Using syringaldazine as the substrate, laccases purified for both Trametes villosa I and Rhus vernicifera have $K_{\mathrm{m}}$ values of 0.058 and $0.043 \mathrm{mM}$, respectively [35].

The purified laccase was able to oxidize a diverse range of phenolic substrates as indicated by the increase in optical density measured at the appropriate wavelength (Table 5). While several of the compounds tested were oxidised by the laccase, syringaldazine appeared to be the best substrate.

Table 4

Properties of the purified laccase SRL1 from S. rolfsii

\begin{tabular}{ll}
\hline Molecular weight & $59 \mathrm{kDa}$ \\
Isoelectric point (pI) & 5.2 \\
Specific activity & $245 \mathrm{nkatal} \mathrm{mg}^{-1}$ \\
pH optimum & 2.4 \\
$T$ optimum & $62^{\circ} \mathrm{C}$ \\
Stabilities (half-life in min) & \\
pH $2.5,30^{\circ} \mathrm{C}$ & $8 \mathrm{~min}$ \\
$\mathrm{pH} 3.0,30^{\circ} \mathrm{C}$ & $12 \mathrm{~min}$ \\
$\mathrm{pH} 4.0,18^{\circ} \mathrm{C}$ & $1 \mathrm{week}$ \\
$\mathrm{pH} 4.5,80^{\circ} \mathrm{C}$ & $<2 \mathrm{~min}$ \\
$\mathrm{pH} 4.5,60^{\circ} \mathrm{C}$ & $60 \mathrm{~min}$ \\
$\mathrm{pH} 5.0,30^{\circ} \mathrm{C}$ & $65 \mathrm{~min}$ \\
\hline
\end{tabular}

Table 5

Substrate specificity of laccase SRL1 from S. rolfsii

\begin{tabular}{lllc}
\hline Substrate & $\begin{array}{l}\text { Concentration } \\
(\mathrm{mM})\end{array}$ & $\begin{array}{l}\text { Wavelength } \\
(\mathrm{nm})\end{array}$ & $\begin{array}{c}\text { Percentage } \\
\text { activity }\end{array}$ \\
\hline Syringaldazine & 0.5 & 525 & 100 \\
ABTS & 5 & 420 & 82 \\
2,6-DMP & 5 & 470 & 60 \\
Guaiacol & 5 & 436 & 21 \\
Catechol & 5 & 450 & 11 \\
Lignin sulfonic acid & 3 & 570 & 0.9 \\
Pyrogallol & 5 & 450 & 7 \\
1,4-Fenilenediamine & 5 & 500 & 0 \\
Ferulic acid & 5 & 287 & 0 \\
Tyrosine & 3 & 280 & 0 \\
\hline
\end{tabular}

Values are given in percentage of activity in nkat ml ${ }^{-1}$ measured at standard conditions.
Typical of fungal laccases, this enzyme was unable to oxidize the simple phenolic compound, tyrosine [36,37].

\subsection{Effect of inhibitors}

The effects of a number of possible laccase inhibitors are shown in Table 6. As expected the most potent of the inhibitors assessed was sodium azide $\left(\mathrm{NaN}_{3}\right)$, requiring the presence of $9.0 \mu \mathrm{M}$ to effect a $50 \%$ drop in laccase activity. The binding of $\mathrm{NaN}_{3}$ to the types 2 and 3 copper sites effects internal electron transfer, thus inhibiting the activity of the laccase. The sensitivity of SRL1 to this inhibitor is demonstrated by the fact that enzyme activity was inhibited by approximately $30 \%$ by the presence of $3.3 \mu \mathrm{M} \mathrm{NaN}$. These findings are in keeping with the general properties of laccase from a diverse range of fungal sources [38,39]. Addition of a water miscible solvent, such as ethanol or methanol, effected a decrease in enzyme activity, similar to those reported for the Cerrena unicolor laccase where ABTS was also used as the substrate [39]. However, organic solvents change the $\mathrm{pH}$ of aqueous solutions and hence, more factors could be contributing to the experimental data obtained [40]. Laccases are inhibited by metal chelators such as EDTA and more strongly by the copper chelators diethyldithiocarbamate (DDC) [2,41]. Type 1 copper can be easily removed by forming a complex since it is exposed to solvents [42]. EDTA up to a concentration of $300 \mathrm{mM}$ showed no effect on SRL1. DDC $\left(\mathrm{I}_{50}=1.2 \mathrm{mM}\right)$ strongly inhibited the enzyme like many other fungal laccases such

Table 6

Laccase inhibitors of SRL1

\begin{tabular}{ll}
\hline Inhibitor & $\mathrm{I}_{50}$ \\
\hline Methanol & $37 \%$ \\
Ethanol & $36 \%$ \\
Thiomine & $0.95 \mathrm{mM}$ \\
L-Cysteine & $0.52 \mathrm{mM}$ \\
$\mathrm{NaN}_{3}$ & $9 \mu \mathrm{M}$ \\
$\mathrm{EDTA}$ & $>300 \mathrm{mM}$ \\
$\mathrm{NaBr}$ & $195 \mathrm{mM}$ \\
$\mathrm{NaCl}$ & $52 \mathrm{mM}$ \\
$\mathrm{NaF}$ & $0.08 \mathrm{mM}$ \\
$\mathrm{DDC}^{\mathrm{a}}$ & $1.2 \mathrm{mM}$ \\
$\mathrm{TGA}^{\mathrm{b}}$ & $0.5 \mathrm{mM}$ \\
\hline
\end{tabular}

a DDC: diethyldithiocarbamate.

b TGA: thioglycolic acid. 
<smiles>O=[N+]([O-])c1ccc(O)c(/N=N/c2ccc3c(O)cccc3c2O)c1</smiles>

Fig. 3. Chemical structure of Diamond Black PV 200 (2-amino-1-phenol4-sulfonic acid $\rightarrow$ 1,5-naphthalenediol).

as from $P$. cinnabarinus [43], from $B$. cinerea [44], from Pleurotus ostreatus, from Trametes versicolor [2] and T. hirsuta [45] where the $\mathrm{I}_{50}$ values were below $1 \mathrm{mM}$. Among the halogens tested, fluoride was the strongest inhibitor as shown previously in the literature [46].

\subsection{Dye decolourization}

A number of textile dyes was decolourized by SRL1 including, Remazol Brilliant Red, Indigo and Lancet Marine Blue (data not shown). Decolourization of Diamond Black PV 200 (MW 350.26), otherwise known as Mordant Black 9 or Eriochrome Black PV was investigated in more detail in this study since this dye is used in much higher quantities than any other dye in a collaborating German wool company. This acid-aniline dye contains a sulfonic group that imparts water solubility on the dye (Fig. 3). The dye was found to be a suitable substrate for the purified laccase and the addition of redox mediators was not necessary. Within a 55-min period the textile dye appeared to be completely degraded due to the laccase activity (Fig. 4). The kinetic parameters of laccase oxidation of the dye were described using the Michaelis-Menten model.

The apparent $K_{\mathrm{m}}$ was estimated to be $16.8 \pm 2.6 \mu \mathrm{M}$ DB or $5.9 \pm 0.9 \mathrm{mg} \mathrm{l}^{-1} \mathrm{DB}$ and the $V_{\max }$ was $1.34 \mu \mathrm{M} \mathrm{min}^{-1}$.

Several other lignolytic fungi were shown to degrade azo dyes investigated including $P$. chrysosporium [47,48], T. versicolor [49], T. modesta [50] and Aspergillus niger [51]. Previously, a purified laccase from A. niger was shown to decolourize one of four diazo dyes tested, demonstrating a specificity for the type or position of substituents on the phenolic ring of the dye structure [14]. However, in most of these studies crude enzyme preparations or fungal cultures were used. One disadvantage of using fungal cultures to effect dye degradation is the accumulation of biomass.

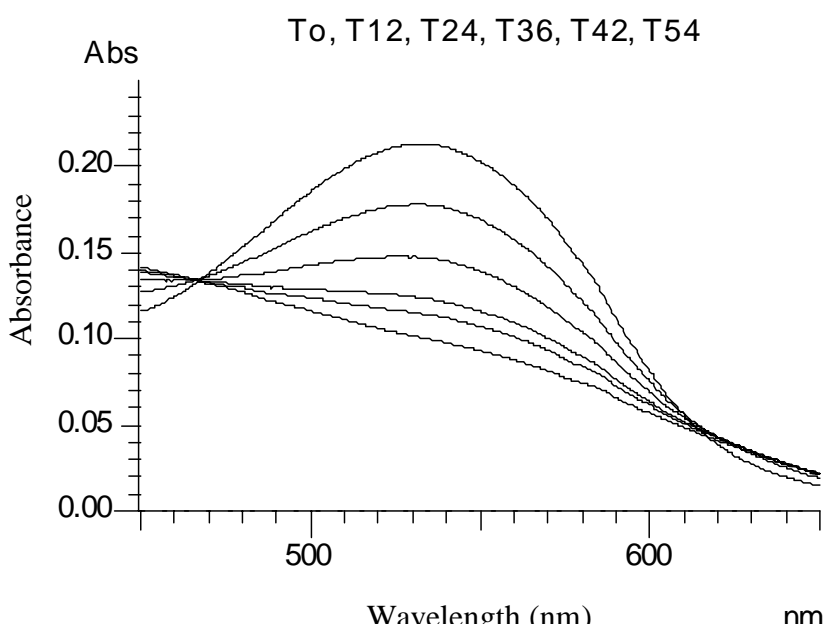

Fig. 4. Absorbance spectra of DB $\left(20 \mathrm{mg} \mathrm{l}^{-1}\right)$ after treatment with the $S$. rolfsii laccase. The scans were performed at $12 \mathrm{~min}$ intervals.

From an industrial point of view it would be simpler to add a laccase solution directly into the wastewater. An attractive feature of this enzyme is the fact that it does not require redox mediators to function efficiently in dye biotransformation. For the treatment of wool dyeing effluents with low $\mathrm{pH}$ values, an acid stable laccase would be desirable. Consequently, the laccase from $S$. rolfsii, which is very stable in the acidic $\mathrm{pH}$ range, may prove to be successful on an industrial scale. Immobilisation of the laccase could further reduce cost of the enzyme and avoid interaction of the enzyme protein with dyes when the treated effluents are reused in dyeing [45].

\subsection{Redyeing}

The crude laccase was immobilized on alumina support. Eighty-three percent of the protein bound to the carrier, corresponding to $0.13 \mathrm{mg} \mathrm{g}^{-1}$ alumina and $72 \%$ of the laccase activity was retained on the carrier material. Previously, between 70 and $98 \%$ of the protein immobilised and 67-96\% of laccase activity, recovery was reported with different carrier materials [52-54]. Out of a number of different carrier materials previously tested for laccase immobilization such as activated carbon [55], Eupergit ${ }^{\circledR} \mathrm{C}$ [56], Sepharose [57], silica-based matrices [58] and porous glass [53,59] only alumina was used in this study as it seems to be more suitable

Table 7

Colour difference on fabrics dyed with C.I. Acid Blue 113 in enzymatically decolourised textile effluents coming from dyeing with C.I. Reactive Black 5

\begin{tabular}{|c|c|c|c|c|c|c|}
\hline \multirow[t]{2}{*}{ Depth of shade (\% o.w.f.) } & \multicolumn{6}{|c|}{ Colour difference, $\Delta E^{*}$} \\
\hline & Liquor 1 & Liquor 2 & Liquor 3 & Liquor 4 & Liquor 5 & Liquor 6 \\
\hline $0.5 \%$ & 2.9 & 1.9 & 2.0 & 2.3 & 2.4 & 2.2 \\
\hline $1.0 \%$ & 1.0 & 1.3 & 1.0 & 1.5 & 1.9 & 1.9 \\
\hline $1.5 \%$ & 0.8 & 0.9 & 0.8 & 0.9 & 1.4 & 1.3 \\
\hline
\end{tabular}


for application in dye decolourization, due to its mechanical stability.

Dyeing effluents decolourized with the immobilized laccase were suitable for redyeing (Table 7), providing considerable fresh water saving. The $\Delta E^{*}$ values for redyeing with 1.0 and 1.5 depth of shade (\% o.w.f.) were in a range which is acceptable to the industry [60-62]. However, these values might certainly be improved by proper adjustments of the standard dyeing protocols. In summary, we have shown for the first time that an acidic laccase from $S$. rolfsii immobilized on alumina can be used for the continuous decolourization of wool dyeing effluents which allows usage of the water for redyeing.

\section{References}

[1] Bourbonnais R, Paice MG. Demethylation and delignification of kraft pulp by Trametes versicolor laccase in the presence of 2,2'-azinobis-(3-ethylbenzthiazoline-6-sulphonate). Appl Microbiol Biotechnol 1992;36:823-7.

[2] Gianfreda L, Xu F, Bollag JM. Laccases: a useful group of oxidoreductive enzymes. Bioremed J 1999;3:1-25.

[3] Thurston CF. The structure and function of fungal laccases. Microbiology 1994;140:19-26.

[4] Harvey BM, Walker JRL. Studies with plant laccases: comparison of plant and fungal laccases. J Biochem Mol Biol Biophys 1999;3:4551.

[5] Sidjanski S, Mathews GV, Vanderberg JP. Electrophoretic separation and identification of phenol oxidases in hemolymph and midgut of adult Anopheles stephensi mosquitoes. J Parasitol 1997;83:686-91.

[6] Alexandre G, Zhulin IB. Laccases are widespread in bacteria. Trends Biotechnol 2000;18:41-2.

[7] Munoz C, Guillen F, Martinez AT, Martinez MJ. Induction and characterization of Laccase in the ligninolytic fungus Pleurotus eryngii. Curr Microbiol 1997;34:1-5.

[8] Shin KS, Lee YJ. Purification and characterization of a new member of the laccase family from the white-rot basidiomycete Coriolus hirsutus. Arch Biochem Biophys 2000;384:109-15.

[9] Eggert C, Temp U, Eriksson KE. The ligninolytic system of the white rot fungus Pycnoporus cinnabarinus: purification and characterization of the laccase. Appl Environ Microbiol 1996;62:1151-8.

[10] Dec J, Bollag JM. Detoxification of substituted phenols by oxidoreductive enzymes through polymerization reactions. Arch Environ Contam Toxicol 1990;19:543-50.

[11] Glenn JK, Gold MH. Decolorization of several polymeric dyes by the ligini-degrading basidiomycete Phanerochaete chrysosporium. Appl Environ Microbiol 1983;45:1741-7.

[12] Abadulla E, Robra KH, Gubitz G, Silva L, Cavaco-Paulo A. Enzymatic decolorization of textile dyeing effluents. Textile Res J 2000;70:409-14.

[13] McMullan G, Meehan C, Conneely A, Kirby N, Robinson T, Nigam $\mathrm{P}$, et al. Microbial decolourisation and degradation of textile dyes. Appl Microbiol Biotechnol 2001;56:81-7.

[14] Soares GM, Costa-Ferreira M, Pessoa de Amorim MT. Decolorization of an anthraquinone-type dye using a laccase formulation. Biores Technol 2001;79:171-7.

[15] Pierce J. Colour in textile effluents-the origins of the problem. J Soc Dyers Colour 1994;110:131-4.

[16] Hillenbrand T. Die abwassersituation in der deutschen papier-, textilund lederindustrie. Gwf Wasser Abwasser 1999;140(4):267-73.

[17] Haltrich D, Laussamayer B, Steiner W. Xylanase formation by Sclerotium rolfsii: effect of growth substrates and development of a culture medium using statistically designed experiments. Appl Microbiol Biotechnol 1994;42:522-30.
[18] Gübitz GM, Hayn M, Sommerauer M, Steiner W. Mannan degrading enzymes from Sclerotium rolfsii: characterization and synergism of 2 endo $\beta$-mannanases and a $\beta$-mannosidase. Biores Technol 1996;58:127-35.

[19] Sadana JC, Patil RV. Cellobiose dehydrogenase from Sclerotium rolfsii. J Gen Microbiol 1985;131:448-54.

[20] Chet I, Huttermann A. Denovo synthesis of polyphenol oxidase (Laccase) during formation of sclerotia in Sclerotium rolfsii. FEMS Microbiol Lett 1982;14:211-5.

[21] Aycock R. Stem rot and other diseases caused by Sclerotium rolfsii. NC Agr Exp St Tech Bull 1966;174:202.

[22] Hermann TE, Champe SP, Kurtz MB. Laccase localized in hülle cells and cleistothecial primordia of Aspergillus nidulans. J Bacteriol 1983;154:955-64.

[23] Gübitz GM, Hayn M, Urbanz G, Steiner W. Purification and properties of an acidic $\beta$-mannanase from Sclerotium rolfsii. J Biotechnol 1996;45:165-72.

[24] El-Katatny MH, Gudelj M, El-Katatny MS, Robra K-H, Gübitz GM. Characterisation of a chitinase and an endo-1,3-glucanase from Trichoderma harzianum Rifai T24 involved in control of the phytopathogen Sclerotium rolfsii. Appl Microbiol Biotechnol 2001;56:137-43.

[25] Niku-Paavola L, Ranua M, Suurnakki A, Kantelinen A. Effects of lignin modifying enzymes on pine kraft pulp. Biores Technol 1994;50:73-7.

[26] Arora DS, Gill PK. Effects of various media and supplements on laccase production by some white rot fungi. Biores Technol 2001;77:89-91.

[27] D'souza TM, Merritt CS, Reddy CA. Lignin-modifying enzymes of the white rot basidiomycete Ganoderma lucidum. Appl Environ Microbiol 1999;65:5307-13.

[28] Fahraeus G, Tullander V, Ljunggren H. Production of high laccase yields in cultures of fungi. Physiol Plant 1958;11:631-42.

[29] Marbach I, Mayer AM, Harel E. Pectin a second inducer for laccase production by Botrytis cinerea. Phytochemistry 1985;24:2559-61.

[30] Otterbein L, Record E, Chereau D, Herpoel I, Asther M, Moukha SM. Isolation of a new laccase isoform from the white-rot fungi Pycnoporus cinnabarinus strain ss3. Can J Microbiol 2000;46:75963.

[31] Bonomo RP, Boudet AM, Cozzolino R, Rizzarelli E, Santoro AM, Sterjiades R, et al. A comparative study of two isoforms of laccase secreted by the "white-rot" fungus Rigidoporus lignosus, exhibiting significant structural and functional differences. J Inorg Biochem 1998;71:205-11.

[32] Galhaup C, Wagner H, Hinterstoisser B, Haltrich D. Increased production of laccase by the wood-degrading basidiomycete Trametes pubescens. Enzyme Microb Technol 2002;30:529-36.

[33] Dittmer JK, Patel NJ, Dhawale SW, Dhawale S. Production of multiple laccase isoforms by Phanerochaete chrysosporium grown under nutrient sufficiency. FEMS Microbiol Lett 1997;149:65-70.

[34] Xu F. Effects of redox potential and hydroxide inhibition on the $\mathrm{pH}$ activity profile of fungal laccases. J Biol Chem 1997;272:924-8.

[35] Xu F. Oxidation of phenols, anilines, and benzenethiols by fungal laccases: correlation between activity and redox potentials as well as halide inhibition. Biochemistry 1996;35:7608-14.

[36] Jung H, Xu F, Li K. Purification and characterization of laccase from wood-degrading fungus Trichophyton rubrum LKY-7. Enzyme Microb Technol 2002;30:161-8.

[37] Mayer AM, Harel E. Polyphenol oxidases in plants. Phytochemistry 1979;18:193-215.

[38] Bollag JM, Leonowicz A. Comparative studies of extracellular fungal laccases. Appl Environ Microbiol 1984;48:849-54.

[39] Gianfreda L, Sannino F, Filazzola MT, Leonowicz A. Catalytic behavior and detoxifying ability of a laccase from the fungal strain Cerrena unicolor. J Mol Catal B-Enzym 1998;4:13-23.

[40] Rodakiewicz-Nowak J, Kasture SM, Dudek B, Haber J. Effect of various water-miscible solvents on enzymatic activity of fungal laccases. J Mol Catal B-Enzym 2002;11:1-11. 
[41] Givaudan A, Effosse A, Faure D, Potier P, Bouillant ML, Bally R. Polyphenol oxidase in Azospirillum lipoferum isolated from rice rhizosphere: evidence for laccase activity in nonmotile strains of Azospirillum lipoferum. FEMS Microbiol Lett 1993;108:205-10.

[42] Yaropolov AI, Skorobogatko OV, Vartanov SS, Varfolomeyev SD. Laccase properties catalytic mechanism, and applicability. Appl Biochem Biotechnol 1994;49:257-80.

[43] Eggert C, Temp U, Eriksson KE. Laccase-producing white-rot fungus lacking lignin peroxidase and manganese peroxidase. Acs Symp Ser 1996;655:130-50.

[44] Slomczynski D, Nakas JP, Tanenbaum SW. Production and characterization of laccase from Botrytis cinerea 61-34. Appl Environ Microbiol 1995;61:907-12.

[45] Abadulla E, Tzanov T, Costa S, Robra K-H, Cavaco-Paulo A, Gübitz GM. Decolorization and detoxification of textile dyes with a laccase from Trametes hirsuta. Appl Environ Microbiol 2000;66:3357-62.

[46] Baminger U, Nidetzky B, Kulbe KD, Haltrich D. A simple assay for measuring cellobiose dehydrogenase activity in the presence of laccase. J Microbiol Meth 2002;35:253-9.

[47] Cripps C, Bumpus JA, Aust SD. Biodegradation of azo and heterocyclic dyes by Phanerochaete chrysosporium. Appl Environ Microbiol 1990;56:1114-8.

[48] Chagas EP, Durrant LR. Decolorization of azo dyes by Phanerochaete chrysosporium and Pleurotus sajorcaju. Enzyme Microb Technol 2001;29:473-7.

[49] Roy-Arcand L, Archibald FS. Direct decolorization of chlorophenolic compounds by laccases from Trametes (coriolus) versicolor. Enzyme Microb Technol 1991;3:194-203.

[50] Nyanhongo GS, Gomes J, Gübitz GM, Zvauya R, Read J, Steiner W. Decolorization of textile dyes by laccases from a newly isolated strain of Trametes modesta. Water Res 2002;36:1449-56.

[51] Graça MB, Soares MT, Amorim P, Hrdina R, Costa-Ferreira M. Studies on the biotransformation of novel disazo dyes by laccase. Proc Biochem 2002;37:581-7.
[52] Davis S, Burns RG. Decolorization of phenolic effluents by soluble and immobilized phenol oxidases. Appl Microbiol Biotechnol 1990;32:721-6.

[53] Rogalski J, Dawidowicz AL, Jozwik E, Leonowicz A. Immobilization of laccase from Cerrena unicolor on controlled porosity glass. J Mol Catal B-Enzym 1999;6:29-39.

[54] Osiadacz J, Al-Adhami A, Bajraszewska D, Fischer P, PeczynskaCzoch W. On the use of Trametes versicolor laccase for the conversion of 4-methyl-3-hydroxyanthranilic acid to actinocin chromophore. J Biotechnol 1999;72:141-9.

[55] Davis S, Burns RG. Covalent immobilization of laccase on activated carbon for phenolic effluent treatment. Appl Microbiol Biotechnol 1992;37:474-9.

[56] D’Annibale A, Rita Stazi S, Vinciguerra V, Giovannozzisermanni G. Oxirane-immobilized Lentinula edodes laccase: stability and phenolics removal efficiency in olive mill wastewater. J Biotechnol 2000;77:265-73.

[57] Majcherczyk A, Johannes C, Huttermann A. Oxidation of polycyclic aromatic hydrocarbons (PAH) by laccase of Trametes versicolor. Enzyme Microb Technol 1998;22:335-41.

[58] Brenna O, Bianchi E. Immobilized laccase for phenolic removal in must and wine. Biotechnol Lett 1994;16:35-40.

[59] Rogalski J, Jozwik E, Hatakka A, Leonowicz A. Immobilization of laccase from Phlebia radiata on controlled porosity glass. J Mol Catal A-Chem 1995;95:99-108.

[60] Harold RW. Textiles: appearance analysis and shade sorting. Text Chem Color 1987;19:23-31.

[61] Steen D. Acceptabilité colorimétrique comparaison des équations CMC et CIE94. L'Industrie Textile 1998;1300:55-8.

[62] Baumann W, Brossmann R, Groebel BT, Kleinemeier N, Krayer $\mathrm{M}$, Leaver AT, et al. Determination of relative color strength and residual color difference by means of reflectance measurements. Part II. Determination of residual color difference. Text Chem Color 1987;19:21-2. 